Sternfeld Das stimmt. Wenn das das Ergebnis unseres heutigen Gesprächs sein könnte, dass wir mit dem Vergleich von Volksbühnenbesetzung, kuratorischen Praktiken und den Kämpfen gegen Gentrifizierung und für Enteignung in Berlin anfangen, strukturell weiterzudenken, würde ich das einen tollen Traum finden.

Adamczak Ja, genau. Und die Strukturen denken wir dabei natürlich immer als Beziehungen.

\title{
Maurício Liesen \\ Becoming Common: \\ Remarks on the \\ (Im)Possibilities \\ of Sharing
}

\begin{abstract}
$\underline{\text { Ex-positions }}^{1}$
In September 2017, an exhibition at a Santander Bank's Cultural Center in the Brazilian City Porto Alegre was canceled after a huge wave of protests (mostly through social networks). The exhibition Queermuseum - Cartographies of Diversity in Brazilian Art, which remained open only a month after its vernissage, gathered artistic productions approaching sexual diversity as well as LGBTQI+ and gender issues. Most of the demonstrators complained that some of the works promoted blasphemy against religious symbols and moreover constituted an apology for violence, zoophilia, and pedophilia. The demonstrations were obviously led by rightwing and conservative movements in Brazil. Faced with this sudden repercussion, Santander's Cultural Center published a statement explaining that those works had been created "precisely to make us reflect on the challenges we must face in relation to gender, diversity and violence." 2 Two days later, however, the Santander Group backtracked and yielded to the pressure, supposedly fearing a boycott against the bank and trying to preserve its image as a financial institution. In a new official press release, the Santander Cultural Center even apologized to all those who
\end{abstract}

1 I would very much like to thank Annika Haas, Maximilian Haas, Hanna Magauer, Dennis Pohl, and Michael Taylor who have generously contributed to the following reflections.

2 Quoted from https://brasil.elpais.com/brasil/2017/09/11/politica/ 1505164425_555164.html. Last access for all websites: November 26, 2019. 
felt offended by some of the exhibition's works: "We hear the demonstrations and we understand that some pictures from the Queermuseum Exhibition disrespect symbols, beliefs, and individuals, which does not align with our worldview. When art is not capable of generating inclusion and positive reflection, it loses its greater purpose, which is to elevate the human condition."
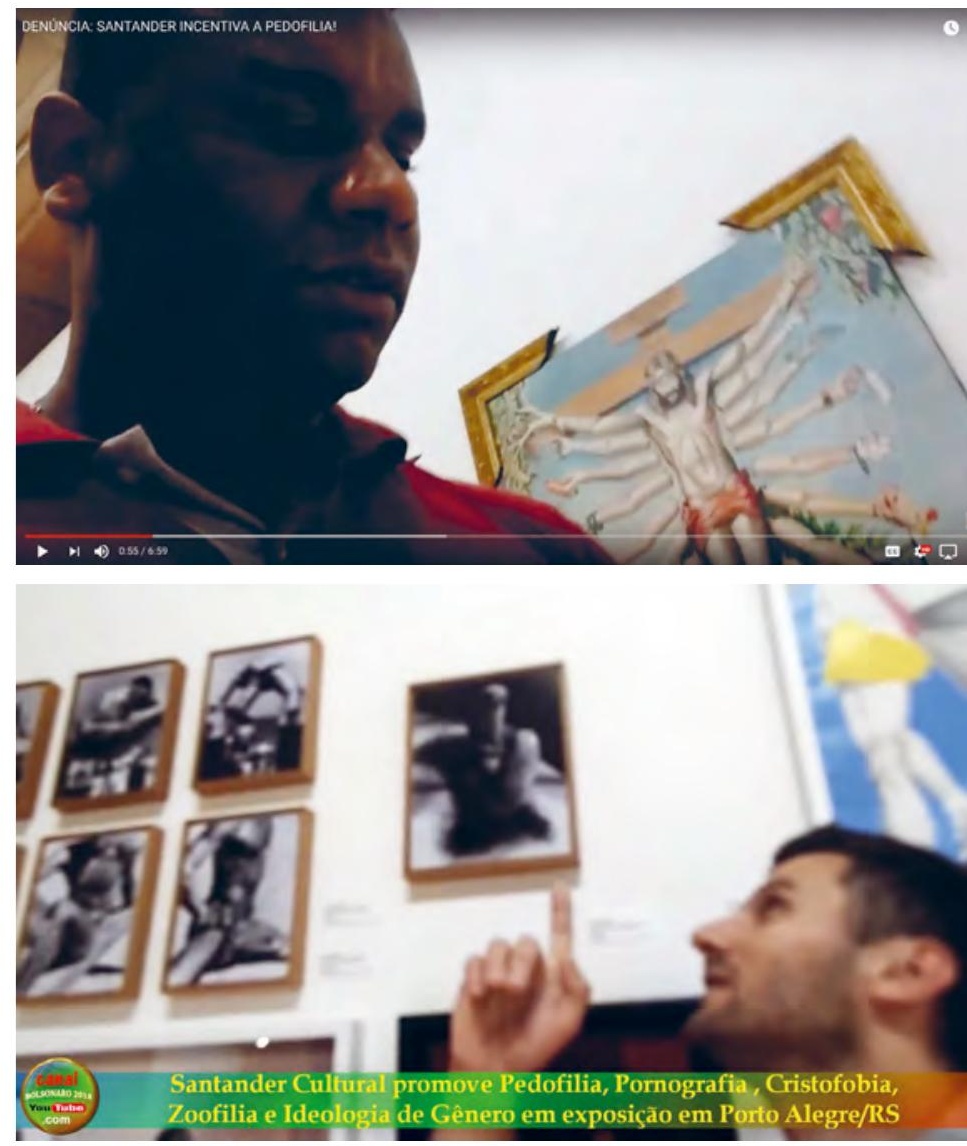

Brazilian bloggers linked to far-right groups who denounced Santander's "degenerate" exhibition through YouTube channels such as BK Tube, and INFORMA BRASIL TV, 2017, screenshots

The documenta 14 in Kassel and Athens in 2017 also met with considerable controversy. Greece was still coming to terms with the 2008 financial crisis, and there was the ongoing issue of refugees entering the country's southern Mediterranean border. From the outset nearly six years ago, when it was announced that the contemporary art exhibition would be split between two cities, vehement criticism arose, such as that expressed by the former and popular Greek finance minister Yanis Varoufakis: "It's a gimmick by which [sic] to exploit the tragedy in Athens in order to massage the consciences of 
some people from documenta. It's like rich Americans taking a tour in a poor African country, doing a safari, going on a humanitarian tourism crusade." 3 From the beginning of the exhibition, anti-documenta posters and graffiti papered city walls and museum entrances. "Dear Documenta," read a stencil of a series signed by "the natives," "I refuse to exoticize myself to increase your cultural capital." 4 In May 2017, the group LGBTQI+ Refugees in Greece, in which migrants and Greek activists work together, stole the work of the Spanish artist Roger Bernat. His project, called The Place of the Thing, involved circulating, through Athens, a replica of a limestone block from the Agora, the ancient marketplace where the trial against the philosopher Socrates took place in $399 \mathrm{BC}$, as part of an elaborate mock funeral, before finally shipping the stone to Kassel to be buried. The artist had invited some art collectives in Athens to help walk the stone over a week to public places as a kind of procession. Then having agreed to take part in it, the group LGBTQI+ "kidnapped" the stone and disrupted the project. ${ }^{5}$ They filmed a video of themselves pounding on the stone like a drum and dancing through the streets as if at a carnival, with satirical subtitles attached:

Your stone may have been deported to Turkey, after appealing twice [sic]. Your stone may be on a flight to Sweden with its new 2,000-euro fake passport. Your stone may be driven to suicide in Moria detention center, desperate for freedom. Your stone may be selling its body to strangers in Pedion Tou Areos. Your stone may be legally recognized as a refugee but sleeping on the street. ${ }^{6}$

Let me describe one more notable event: in March 2017 the painting Open Casket by the North American artist Dana Schutz was exhibited at the biennial of the Whitney Museum in Manhattan. The work was inspired by the tragedy of Emmett Till, a black fourteen-year-old boy who was lynched by two white supremacists in Mississippi in 1955. Till's body had been mutilated, but his mother refused to hold a wake with a closed coffin, so that his disfigured body could raise awareness of the awful realities of racism in the United States. The defendants were acquitted in court but subsequently confessed to the crime. Shortly after the opening of the Whitney biennial, criticisms of cultural appropriation appeared, claiming that Schutz, a white artist, shouldn't be exhibiting her depiction of an image that has been so iconic for the African-American civil rights struggle. African-American artist

3 Quoted from https://www.spikeartmagazine.com/en/articles/ doing-documenta-athens-rich-americans-taking-tour-poor-african-country.

4 Quoted from https://www.nytimes.com/2017/04/05/arts/design/ documenta-german-exhibition-greek-crisis.html.

5 See a more detailed description at: http://hyperallergic.com/382407/ lgbtq-refugee-rights-group-steals-artwork-from-documenta-in-athens.

6 The video was posted on the Group's Facebook page https://www.facebook.com/ lgbtqirefugeesingreece/. 

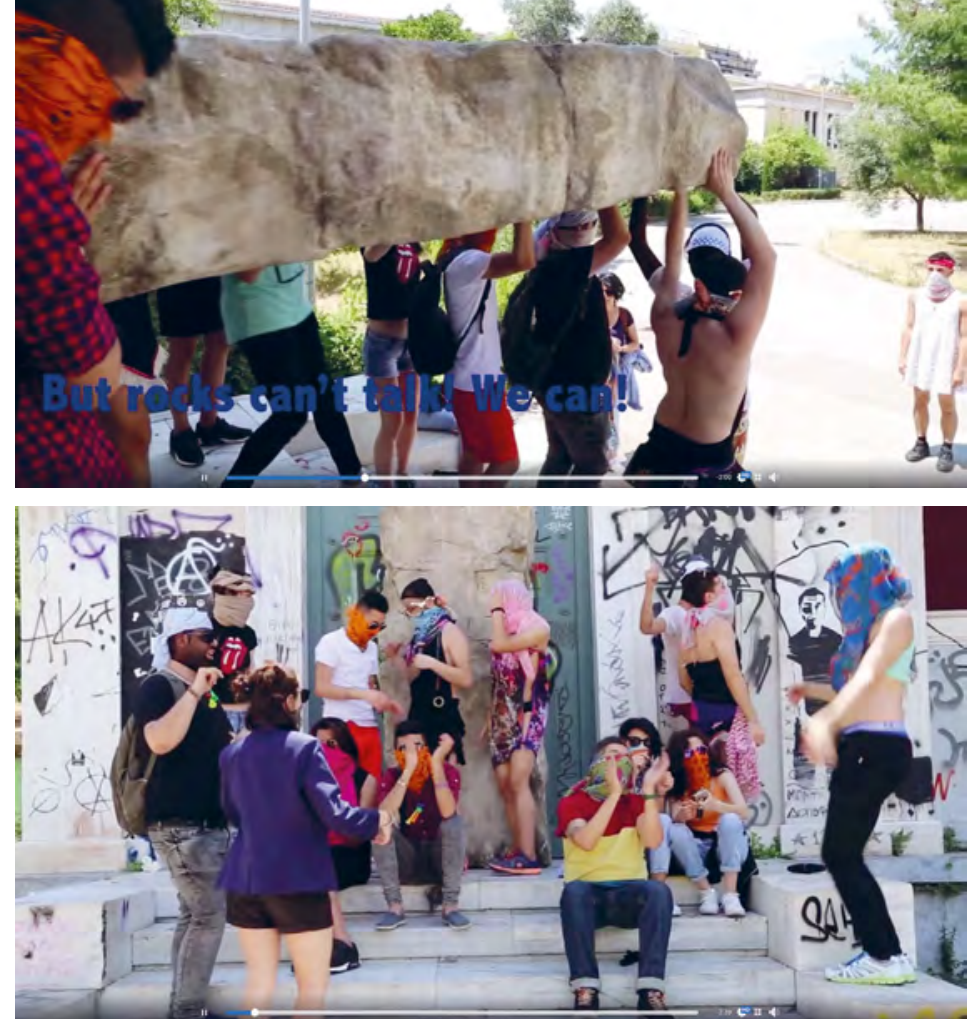

LGBTQI+ Refugees in Greece, \#Rockumenta Performance, 2017, screenshots

Parker Bright, for instance, began to silently protest by standing in front of the painting wearing a t-shirt with the sentence "Black Death Spectacle" on the back. Artist Hannah Black wrote a letter to the museum's curators demanding both the painting's removal and destruction: "The painting should not be acceptable to anyone who cares or pretends to care about Black people because it is not acceptable for a white person to transmute Black suffering into profit and fun."7 In her response, Schutz appealed to an empathetic force of art, saying that her commitment to the painting derives from her empathy with his mother, because she also has a child. In a petition targeting the painting, Hannah Black later wrote that "white free speech and white creative freedom have been founded on the constraint of others, and are not natural rights. The painting must go."8

We thus have three very different scenarios here. For me, they are starting points to examine not just the effects, on artworks, of the scenarios becoming public and becoming common, but how their "ex-position" is intricately re-lated to what makes them art. Yet what could easily be misread as a radical, and yet broad generalization of "art," is not operative here as a definition. Instead, it describes a perspective of philosophy of communication about art that I am adapting here for a view through the lens of relations that co-produce art not only in a poeitic sense, but a political one. The three

7 Quoted from https://www.textezurkunst.de/articles/baker-pachyderm/.

8 Quoted from https://www.nytimes.com/2017/03/21/arts/design/painting-ofemmett-till-at-whitney-biennial-draws-protests.html. 
key terms of the conference for which this paper was originally written ${ }^{9}-$ appropriation, mediation, and figuration - contributed to clarify this perspective. As those exhibitions show us, they stand for different dynamics related to artworks in public. Conversely, what unites them here is the mere fact that their occurrence depends on an in-between (public/common), i.e., between the audience and the works. ${ }^{10}$ In the aforementioned scenarios, this in-between is the conditio sine qua non for figuration, mediation, or appropriation of aesthetic phenomena and helps to frame them: what we see is a conservative protest that was provoked by artistic figurations of nonnormative ideas and bodies, and that managed to overturn it; a performance or political action against a supposed inability of a major event in the art world aiming to mediate the diversity and particularities of a historical, geographic, and political situation; and finally, a denunciation of cultural appropriation that reveals the permanence of mechanisms of exclusion, that is, the insistence of spaces that should be occupied by artists whose role as protagonists is being denied because of their gender, social status, ethnicity, or skin color.

Without wishing to discredit the various particularities of those examples, I would like to emphasize that on the surface of the described events is the fact that when an artwork becomes public, it will also raise problems beyond or below its aesthetic phenomenality. Figuration, mediation, and appropriation of artistic works are, among others, ways of acting or inhabiting a common space that is not always related to the aesthetic specificity of artistic objects. Hence, their reflection is for me deeply connected with the notion of "the common" as a public or open space of relations, in which every aesthetic phenomenon inevitably finds itself interwoven with ethical and political issues. In what follows, I intend to read those scenarios as illustrations of a phenomenon that I would tentatively call "ex-position," i.e., a way of showing a space of sharing that could be synthesized in the concept of the public or, more radically, the common. On the one hand, artistic expression cannot, in terms of representation's freedom, be curtailed. Hence questions such as "what can be expressed" or "who can express it" would not belong to works of art. But on the other hand, in the commonality of what is public, art is not only about representation but also about representativeness, that is, a political problem that does not refer to the limits of expression but to the occupation of a place of visibility, of defining who is marginalized or silenced. Hence, the problem of representativeness goes hand in hand with the epistemological dimension

9 "How to Relate: Appropriation, Mediation, Figuration": Annual Conference of the DFG Research Training Group "Knowledge in the Arts" took place July 5-7, 2018, at the Berlin University of the Arts. See www.udk-berlin.de/en/research/ temporary-research-institutes/dfg-research-training-group-knowledge-in-thearts/event-archive/how-to-relate-appropriation-mediation-figuration/.

10 These three concepts have a complex tradition disseminated in different fields of the humanities. While conceptual refinement escapes the proposal of this article, the meanings attributed to each of these terms will be discussed gradually in this text. 
raised by the concept of appropriation. In other words, it is not just about a symbolic appropriation, but the emulation of a knowledge form produced from a particular experience of a subject whose very possibility of expression has been denied.

What I would like to stress is that freedom of representation does not mean being free from criticism of alleged injustice, because when a work is exhibited in public, it is "ex-posed," that is, situated out in the open, in the common. And this may be understood as an aporia, since art exists only when communicated, when shared in this common space between humans, at the same time as sacrificing its status of a mere object of art. Art only is as long as it is in this "ex-posure," that is, when it is publicized, when it takes part in what is public; at the same time, it loses its particularities in the common. ${ }^{11}$ But art occupies a particular place in what is "public" or common, namely, the one capable of producing reflexivity. The political, ethical, and epistemological dimensions of art arise from its potential to mediate social tensions, from figurations of what is not or cannot be represented and from the transforming re-appropriation of signs and values. If these dimensions that stray from the realm of art are situated beyond or below what we might call "the artistic," it is through art that these and other dimensions are mediated, thematized, exposed, put into question. Moreover, because all those spheres inhabit a common space, art is never exempt from criticism, errors, and confrontations.

This interdependence of the becoming-public of every object of artistic expression, which always disfigures it (and not only in respect to the artist's intention, since the chain of relationships in this public space is unpredictable) but at the same time constitutes it as such, is an expression of the paradox that art is never "just" art. It is only in this common sphere of vulnerability (for there is a primacy of "being exposed" rather than "showing itself") that art figures and is disfigured, appropriates and is dis-appropriated, mediates and is disrupted. By sharing themselves in this chain of relations of "the common," artistic objects unfold potentialities that are not only aesthetic but also ethical, political, and social, whose effects and affects are hard to disentangle - in the common there are not only objects but ex-positions. This

11 And here I follow, as it were, a bottom line of what might be called communication philosophies - at least since Karl Jaspers and which can be found in very different authors, such as Georges Bataille, Hannah Arendt, Emmanuel Levinas, or Jean-Luc Nancy - and that could be summarized by the following quote: "What is not realised in communication is not yet, what is not ultimately grounded in it is without adequate foundation. The truth begins with two" (Jaspers, Karl, Way to Wisdom: An Introduction to Philosophy, Connecticut, 1964, p. 124). Furthermore, the notion of "the common" here does not have the meaning of ordinary or even mainstream but denotes rather an ontological sense of a sharing space that occurs in-between human beings. So even as a ritualistic or clandestine expression, art, whatever its definition might be, will always also be something addressed to the common and, therefore, always "impure," i.e., exposed and vulnerable to others or an otherness "outside" of the artistic/ aesthetic domain. 
is what I intended to show with the three examples I used above, as a wellspring for my argument. The repercussions of these three artistic events were impressed not only on the public but also on the aesthetic objects themselves. When art becomes public (and according to the argument presented here, this happens only to the extent it is publicized or ex-pressed), when it inhabits a common or public realm, it is subject to something that goes beyond its particularities but that cannot be just turned off without the risk of making the art itself disappear, as is the case, for example, with Schutz's painting. In this sense, mediation, appropriation, and figuration would only manifest themselves as forms of relationships when sharing themselves in a kind of public realm outlined here as the common. Against this backdrop, I would like to consider the question of the common as the concept par excellence for the possibility of relation, as a precarious horizon that is constantly displaced and that produces a community through communication, that is understood, for its part, as the communal sharing of the common and of the partaking in the public. ${ }^{12}$ Hence, I would like to relate and develop these concepts that I have presented so far in a somewhat aphoristic and dispersed way.

\section{What We Have in Common Is What We Don't}

Etymologically derived from the Latin adjective püblïcus, the public refers to what belongs to the state and the people (pŏpŭlus) or to what is common (communis). ${ }^{13}$ The word was a translation of the Greek adjective koinos, ${ }^{14}$ which, in turn, can be understood to mean "common," "ordinary," and, in social and political relations, as "shared in common," "public," or "belonging to generality." Koinon, the noun form of the adjective, was, in the governmental sense, similar to Latin res publica, "the public thing." From koinos, the derivative form koinonia means "community," "sharing in," "communion," and also "communication." In general, it referred to the community of those who were somehow entitled to participate in political life. At least since Aristotle's koinonia politike (the political community) ${ }^{15}$ was opposed to other types of communities and partnerships such as the household (oikos) and the village. The polis, ${ }^{16}$ as the highest form of community, was the sphere where human beings find their own condition as humans. Therefore, the polis does not

12 For this notion of sharing (partage) and its interrelations with the concept of communication and community, see Nancy, Jean-Luc, The Inoperative Community, Minneapolis 1991.

13 The full range of meanings can be found under püblicus in https://www.onlinelatin-dictionary.com/latin-english-dictionary.php?lemma=PUBLICUS200.

14 The full range of meanings can be found under "koinos" in Liddell \& Scott, A Greek-English Lexicon, http://www.perseus.tufts.edu/hopper/text?doc= Perseus\%3Atext\%3A1999.04.0057\%3Aalphabetic+letter\%3D*k\%3Aentry+ group\%3D138\%3Aentry\%3Dkoino\%2Fs.

15 Aristoteles, Política, trans. Maria Aparecida de Oliveira Silva, Sâo Paulo 2019.

16 A discussion about the concept of polis can be found in Cassin, E. Apter, J. Lezra, M. Wood (eds.), Dictionary of Untranslatables: A Philosophical Lexicon, Princeton 2014, pp. 801-803. 
result from an arbitrary reunion of individuals but is based on the irreducible relational, communal, and communicational dimension of the human being:17 for that reason, man is a living political being (politikon zoon). Unlike English or Portuguese, the German language even preserved those derivations between the words "das Gemeine" and "Gemeinschaft," but the proximity of "gemein" to terms like communion and communication was lost. At the same time, this language offers us a word highly valued by theories of communication, namely, "Öffentlichkeit," specially in the concept elucidated by Jürgen Habermas, ${ }^{18}$ which is frequently translated into English as the public sphere. Furthermore, scholars have already largely elaborated the derivation of the concept of Öffentlichkeit from the terms "public" and "common," not only as a delimitation of an area of social action and accountability with a fundamentally different normative character from what is "private" but also as a type of common space with a particular communicational structure or a sphere of communicative action with specific and sophisticated characteristics and functions. ${ }^{19}$ It is worth noting that "öffentlich," the adjective inherent to the word "Öffentlichkeit," means "before the eyes of everyone" or "what can be used by anyone"; and that it derives from the word "das Offene" (the open). The translation of "Öffentlichkeit" as a public sphere is quite illustrative. The public is always a space of visibility, a place that allows anything to "appear." The market and the agora in classical antiquity are places where that sphere also gains objective delimitation. By being an open space, it always emerges as a possibility and a danger. And because it is the place where things become visible, taking part or sharing in it becomes an imperative for religion, science, philosophy, and art. But this "sharing in common" presents itself in a rather complex and paradoxical way. The common, the public, or the open are nothing here but rather words intended to outline this complexity. Based on those general etymological derivations, I would like to discuss conceptual contrasts and contradictions in order to highlight the peculiarity of the concepts of appropriation, mediation, and figuration as ways of acting in what has been outlined here as the common.

For the German Philosopher Hannah Arendt, the public is not only a sphere of political freedom and equality that arises whenever citizens act together through discourse and persuasion; it is also the common world, a shared and

17 It is always relevant to emphasize that the ancient Greek citizen was always the man, born in the polis and possessor of goods. Women, slaves, and children were deprived of public life. My reference to Aristotelian thought follows a gesture initiated at least by Hannah Arendt in invoking it more as a horizon for rethinking the space of action between humans than a nostalgic attitude of reasserting the Greek public man.

18 Habermas, Jürgen, The Structural Transformation of the Public Sphere: An Inquiry into a Category of Bourgeois Society, trans. Thomas Burger, Cambridge 1991, pp. 1-14.

19 See Gerhardt, Volker, Öffentlichkeit: die politische Form des Bewusstseins, München 2012; Peters, Bernhard, Der Sinn von Öffentlichkeit, ed. Hartmut Weßler, Frankfurt am Main 2007, pp. 55-56. 
public world of human artifacts, institutions, and environments that separate us from nature and provide a relatively permanent and lasting context for our activities..$^{20}$ Most fundamentally, it is a space of appearance that constitutes us as human beings. Only when others are there in the open with me, listening and seeing what I see and hear, can we take the world as real. The opposite term for this public realm is the private one. More than that, for Arendt the public can only be understood in relation to the private. She argues that both are essential for the practice of citizenship: the first providing the spaces where it can flourish, the latter providing the stable basis from which public spaces of action and deliberation can arise. However, as I read her book, the public realm is neither the sum of private interests, nor is the greatest common divisor of this sum, nor even the total of informed personal interests. Rather, it describes a world that is beyond the self, the I, the private person. It relates to what was there before our birth and what will be there after our death, a world that is incorporated into activities and institutions. It refers to the interests of a public world that we share as citizens and that we can pursue and enjoy only by going beyond our private interest. This analysis between the public and private realms assumes a critical dimension in Arendt's work. As I read her, the biggest problem of modernity would be the fact that the private realm subjugated the public, placing both the economy (the oikos) and the individual at the center of relationship between human beings.

The public does not mean that something is owned by everyone; rather, it refers precisely to the denial of any possibility of property. When something is privatized, it naturally ceases to be public. Another name for this process of taking something that is from another to itself would be that of appropriation. But if what one takes for oneself is "common," that is, it belongs to no one? Could one still be accused of performing a privatization? There is a tension between appropriation and expropriation that is constitutive of the sphere of the common.

\section{Appropriation as Participation}

According to the philosopher Rahel Jaeggi, the public space does not exist as a public space without its "public" appropriation. ${ }^{21}$ This sounds like an oxymoron, but for me it illustrates that whatever is appropriated is no longer something foreign, strange, independent, or with no relation, no point in common with the appropriator, in any relevant sense. What is assimilated is only what one can actually already own. In other words, appropriation can only exist in the sphere of the common while eliminating, in this process, what should be common by taking for itself what belongs to another. From the eradication of the constitutive strangeness of being in common, the character

20 Arendt, Hannah, The Human Condition, Chicago 1958, pp. 22-78.

21 Jaeggi, Rahel, "Aneignung braucht Fremdheit," in https://www.textezurkunst.de/46/aneignung-braucht-fremdheit/. 
of the process of appropriation changes because what belongs to the other remains something always irreducible, impossible to be appropriated. In the process of appropriation, there is always the tension between something that is given to privatization and something that completely denies it. It is important to emphasize here the relationship between strangeness and its accessibility, because objects of appropriation - which can take on many forms as seen in the beginning: from public space, to material artwork, to the possibility to be seen and heard, etc. - are neither strange nor familiar. ${ }^{22}$ In this sense, appropriation can be understood as participation and, by extension, as countercommunication. Etymologically, communication is an activity of making (or turning) something common. Appropriation is the opposite process. It is necessary, so to speak, for "entering and exiting" public space. To appropriate is to participate, but - if we just think of Schutz's painting as a very strong example - this is by no means nonconflictual.

From Latin pars (part) and carpere (to grasp, to take, to take), the word's etymology refers to a process of appropriation and transformation that has emerged from the taking of what is common or shared (i.e., of what is communicated). In turn, the Latin word "participatio" is a translation of the Greek term "methexis," which Plato used, not without reason, to describe the relationship between ideas and things in the sensible world. ${ }^{23}$ Participation has, in other words, a medial or mediation function, such that things retain the properties of ideas; that is, they take part in them, although they can never identify with them. Therefore, the definition does not take part in the conceptualized thing, but only the opposite: the objects of the world participate in the world of ideas. Participation depends on a process of mediation and production of differences from (re)appropriations and transformations. It can be understood as a paradoxical intertwining of inclusion and exclusion, proximity and distance.

The play between participation and communication is constitutive for the public space. And what I am here calling "the common" does not constitute an egalitarian and consensual sphere but rather a space of conflict where singularities, instead of individualities, meet and confront each other. The notions of singularity and plurality are ways of apprehending a disposition prior to any social formation. The relation between these two elements would be, so to speak, the "matter" of the social, since it is through them that the problem of the constitution of a "we" from an "I" or vice-versa is articulated. The singularity - which can only exist in the plural - is finite and comes from nothing. It is a bottomless foundation, since it cannot be produced

22 Incidentally, this discussion of appropriation as a relationship is Jaeggi's starting point for repositioning the concept of alienation within social philosophy: alienation is - and remains, according to Marx's and Arendt's thought - the impossibility of appropriating the world as a result of one own activity. See Jaeggi, Rahel, Entfremdung: Zur Aktualität eines sozialphilosophischen Problems, Frankfurt am Main 2016, p. 20 et seq.

23 Plato, Parmenides, trans. Samuel Scolnicov, Berkeley and Los Angeles, 2003. 
or derived or extracted or operationalized. I'm thinking here along the lines of French philosopher Jean-Luc Nancy: "There is nothing behind the singularity but there is, outside and within it, the material and immaterial space that distributes it and shares it as singularity, distributes and shares the confines of uniqueness - what it means to say of alterity - between itself and itself."24 Therefore, there is no singular being without another singular being. However, even in mutual relation, there is no communion between these singular beings that lead them to a higher totality. If the community is not the presupposition and not even the result of a communion between the beings affected by the externality, what would, therefore, assume the place of this communion? Nancy once more: "In the place of such communion there is communication. What this means is that, in very precise terms, finitude itself is nothing; it is neither a background nor an essence nor a substance. But it appears, it presents itself, it exposes itself and so it exists as communication."25

However, to take part in the common, the singularities must sacrifice what is their very own. This sacrifice can be understood as a primordial debt. This sense could be already found in the Latin word "communis." This term is basically made of two words: "cum" (with) and "munus" (a burden, a debt, a task). Among the variety of meanings of the word "munus," the Italian philosopher Roberto Esposito emphasizes the sense of "to owe something" - as a duty, as something that is imposed (an onus) to answer. As the philosopher explains, the munus "indicates only the gift that one gives, not what one receives. ... The munus is the obligation that is contracted with respect to the other and that invites a suitable release from the obligation." 26 Therefore, such forced donation implies as much a loss as a grant - not a sharing of something owned. You give something that cannot keep to yourself, even in the mutuality of giving. For this reason, the common characterizes the encounter of singularities who are united not by a "property" but by a duty or a debt. In this sense, as a gift and anathema, the being in common is an incessant task of transforming relationships between beings. It has no meaning, except the communal sharing itself. The common is actually the background from which meaning becomes possible.

The "cum/with" present in expressions like common, community, and communication points out something precarious, incomplete, but at the same time essential for human existence, which can only exist as "coexistence." This constitution of existence as coexistence or, as what I call here, the common, is by no means something new in the humanities and has been elaborated by a variety of philosophers, from Aristotle to Martin Heidegger, Karl Jaspers, Hannah Arendt, Georges Bataille, and Jean-Luc Nancy, to name a few.

24 Nancy, Jean-Luc, The Inoperative Community, Minneapolis 1991, p. 27.

25 Nancy 1991, p. 28.

26 Esposito, Roberto, Communitas: The Origin and Destiny of Community, trans. Timothy Campbell, Stanford 2010, p. 5. 
Presenting the common as a kind of baseless foundation of being-together may be understood as a critique of any identity argument that seeks an original cause, a purity or origin, and that - different than identity politics rejects a pluralistic and differentiated approach to it. Being-in-common is, in contrast to such notions of identity, always impure; it is a mixture of what is in the proximity of being in common, what the French philosopher Jean-Luc Nancy has called mêlée: 'it is not that identity is always 'on the way,' projected onto the horizon like a friendly star, like a value or a regulative idea. It never comes to be; it never identifies itself, even as an infinite projection, because it is already there, because it is the mêlée."27 Mêlée or mixing therefore is nothingit only happens. So what we have in common is what we do not own.

\section{Common Paradoxes of Mediation and (Dis)Figuration}

As I stated earlier, the ontological dimension of the common is followed by an important reflexive and medial dimension. Artworks reveal that relation, each in their particular way, and may help enlighten it. Again, connecting this realm to political theory, it has to be said first that it is through the common that "what is one's very own" - that which cannot be shared - is exposed. Just as plurality can only exist as a co-presence of singularities, the political deals with being-together-and-with-each-different-other, and it is only in the in-between space of the political that freedom can exist, for my freedom is always a freedom with-the-other. At this point, I would like to again refer to Hannah Arendt, when she states that the function of politics would be to organize "those who are absolutely different with a view to their relative equality and in contradistinction to their relative differences." 28 Hence, the being-in-common is always governed by the form of the political, understood as the disposition of powers, places, and roles in this common. As the French philosopher Jacques Rancière explains, "political activity is whatever shifts a body from the place assigned to it or changes a place's destination. It makes visible what had no business being seen, and makes heard a discourse where once there was only place for noise; it makes understood as discourse what was once only heard as noise."29 Still following Rancière's thinking, art and politics have a common origin. According to him, "artistic practices are 'ways of doing and making' that intervene in the general distribution of ways of doing and making as well as in the relationships they maintain to modes of being and forms of visibility'." 30 Therefore, art compels the communicants and participants of the public sphere to deal with their conflicts. In reference to the three examples from the beginning of this essay, the appearance of the abovementioned works in the public reveals something that is always beyond

27 Nancy, Jean-Luc, Being Singular Plural, trans. Robert D. Richardson and Anne O’Byrne, Stanford 2000, p. 155.

28 Arendt, Hannah, The Promise of Politics, ed. Jerome Kohn, New York 2005, p. 96.

29 Rancière, Jacques, Disagreement: Politics and Philosophy, Minneapolis 1999, p. 30.

30 Rancière, Jacques, The Politics of Aesthetics: The Distribution of the Sensible, trans. Gabriel Rockhill, New York 2004, p. 13. 
the art object, while at the same time something is exposed because of them: this might be the growth of conservative thinking in Brazil after the juridical and media coup that impeached President Dilma Rousseff and caused increasing lack of faith in democratic institutions and values in the country (in reference to the cancelation of the Queermuseum's exhibition); or forms of over- and underrepresentation of minority groups (by the \#rockumenta performance); or the imperative to make voices heard that were silenced during centuries of colonial oppression (one thinks here about "the painting must go" quarrel). And all the critiques about the nonidentical "we," the impossible inclusion of everyone, remind us that foundations or origins will never be defined once and for all. They remind us that the common and the unity of the collective are neither original, nor presented, nor previously given, nor deductible, but always delayed, displaced, and extended. ${ }^{31}$

Reflecting on the contradictions of the common means taking into account the fact that every public process of figuration implies a dis-figuration, every process of mediation entails an amediality, and every process of appropriation involves a process of expropriation. But I will not extend the discussion about the process of appropriation and its consequent expropriation as the elementary tension of the common space, for I have already said this before by suggesting that what we have in common is precisely what we do not own. Instead, I would like to add something about the other two forms of relation. The pair "figuration-disfiguration" can be grasped not only by the present tension between representation and representativeness, as I briefly elucidated at the beginning of my discussion here, but also in the impossibility of figuration of the common, under the risk of granting it a unique character. This is the paradox of every art of the ordinary or every aesthetics of the common, which, in presenting it as such, singles it out in its extra-ordinary form. The process of mediation, on the other hand, depends on a pre-given, something that puts it into operation. This "something" is the common sharing itself that must be communicated but cannot be mediated by this same operation, because it is its condition. At the same time, this kind of "condition of possibility" always remains an excess of the process of mediation that at every moment threatens its realization. This excess, which does not participate in mediation but disrupts it, can be apprehended as an amedial trace. To illustrate these two aspects, let me return once again to the events presented at the beginning of this paper, particularly the work by Catalan theater director Roger Bernat, who is known for challenging the boundaries between fiction and reality by stressing, at the same time, theater as real life through the performative unpredictability and life as role-play through predictability and its playful characters. ${ }^{32}$ In the piece with the circulating replica of a

31 This assumption is deeply related to what Marchart called post-foundational thinking. See Marchart, Oliver, Post-Foundational Political Thought: Political Difference in Nancy, Lefort, Badiou and Laclau, Edinburgh 2007.

32 In his work Pendiente de voto (2012), for instance, Bernat transforms the audience into a parliament to reflect on democracy and manipulation. In the same vein, Please, 
limestone block in Athens that I referred to in the beginning, The Place of the Thing, 33 there is a kind of paradox that allows the thematization of what is common at the moment of "failure" of the performance itself in its attempt to mediate the common in its ethical and political aspects. First, there is an impossibility of figuring the public space, or an agora, since the metastructure "this is a play" or "this is a performance" removes the irreparable dimension of the common, no matter how the public is shown as unpredictable. At the same time, the constitution of the performance itself is constantly threatened by what is "on the other side and beyond" of performance, namely the common. This might be someone who refuses to give the first input for the development of the artwork, either through the lack of involvement of participants or any other unforeseen event that disarms the performance device or, as in the case of The Place of the Thing, the hijacking "counterperformance" of the art collective LGBTQI+ Refugees in Greece. In trying to singularize what cannot be singularized, this work shows precisely what escapes it: the common or public realm is what cannot be enacted.

\section{Public Asymmetries}

As some final considerations, I would like to give a rough sketch emphasizing two more aspects that should guide a revision of the concept of the common that would be able to shift the focus on the forms of relation to the forms of relationship. By this I want to reaffirm the anthropological, but not anthropocentric, role of the common/public sphere.

The first aspect is the violence that belongs to that sphere. The common is presented as a space of an exposure, of being exposed, and for this reason it constitutes itself as a propitious space for violence. It is unpredictable, out of control, and hence constitutes a place of vulnerability. According to the philosopher Judith Butler, violence delineates a physical vulnerability that we cannot escape, which we cannot finally solve in the name of the subject, but which can help to understand that none of us is completely delimited, separated from everything, but rather that we are all in our own skin, delivered into the hands of others, at the mercy of others. ${ }^{34}$ This is a situation, it follows from Butler, that we do not choose. It forms the horizon of choice and underlies our responsibility. In this sense, we are responsible for it, because

Continue (2011) is an attempt to highlight "theatricality" as one of the layers of reality itself, by enacting a trial of the Shakespearean character Hamlet in a "real" court of law. In Domini Public (2009), Bernat proposes a participatory performance in which people are guided by headphones to act among passers-by in a public space. The idea is to confront the participants with their performances, their choices, and the consequences of being manipulated by the director's instructions.

33 More information can be found at http://rogerbernat.info/en-gira/parlamento-titulo-de-trabajo-proyecto-2012/; http://rogerbernat.info/en-gira/please-continue-\%E2\%80\%93proyecto-2011\%E2\%80\%93/; http://rogerbernat.info/en-gira/domini-public/;

http://rogerbernat.info/en-gira/please-continue-\%E2\%80\%93proyecto-2011\%E2\%80\%93/; http://rogerbernat.info/en-gira/domini-public/.

34 Butler, Judith Giving an Account of Oneself, New York 2005, p. 100. 
it creates the conditions under which we take responsibility. We do not create it, and so we must be attentive to it. At this point, the ethical dimension emerges within the problematic of the common. That is why the public space cannot be a symmetrical one.

The second point arises from a necessity to reconsider the common from the perspective of a critical theory. This means that it is not enough to subvert the concept of the ordinary beyond its banality and ordinariness, in order to embrace the plural encounter of singularities, but especially if we start from the fundamental opposition to what is private, individual and appropriative, the concept of "common" must become a critique not only of liberal modernity (in Arendt's terms), but a critique of contemporary neoliberal economy, which - primarily in the Global South - destroys institutions, goods, and services that should be public, which makes work and collectivities precarious, which erects cities without any commonality based on high walls, gated communities, few spaces of collective circulation and ever smaller apartments.

As I briefly discussed in this essay, the common is established by the communication in its impossibility of the in-dividual. The intention of bringing to the artistic debate the common as plurality and within a theoreticalcommunicational perspective was not only to reaffirm the impossibility of an argument about "l'art pour l'art" when it comes to the exposition of artistic works, but also to illustrate a complex field that will always traverse the artistic in its mandatory process of ex-position, that will always interweave it in asymmetrical ethical and political threads.

\section{Annika Haas \\ Relationalität elliptisch gedacht Elliptic Relationality}

Die Frage How to relate ...? kann für sich stehen oder als Ellipse gelesen werden. Dann verlangt sie nach einem Objekt, zu dem eine Beziehung besteht: How to relate to ...? Wie sich $\mathrm{zu}$... verhalten? Oder: How to relate $A$ to $B$ ? Wie verhält sich das eine zum anderen? Auch im Deutschen setzt hier die Grammatik voraus, dass Subjekt und Objekt gegeben sind und zwischen beiden ein Verhältnis besteht. Nicht offensichtlich ist dabei jedoch die Frage nach der Beziehungsweise. Welchen zahlreichen Bedingungen es unterliegt, wie etwas miteinander in Beziehung steht, wird in der hier gewählten Betrachtungsperspektive deutlich: Es sind unter anderem Sprache und Schrift, die daran mitbeteiligt sind, wie wir Relationen denken, wie wir uns auf eine Sache beziehen oder meinen, die Dinge zueinander ins Verhältnis setzen zu können. Es ist also nicht arbiträr, was und wie etwas miteinander in 